\title{
Nafion-layered silicate nanocomposite membrane for fuel cell application
}

\author{
Jean-Michel Thomassin ${ }^{a}$, Christophe Pagnoulle $^{\mathrm{a}}$, Didier Bizzari $^{\mathrm{b}}$, \\ Giuseppe Caldarella $^{\mathrm{b}}$, Albert Germain ${ }^{\mathrm{b}}$, Robert Jérôme ${ }^{\mathrm{a}}$ * \\ ${ }^{a}$ Center for Education and Research on Macromolecules (CERM), University of \\ Liège, Sart-Tilman, B6, 4000 Liège, Belgium; Fax (32)4-3663497; rjerome@ulg.ac.be \\ ${ }^{\mathrm{b}}$ Laboratoire de Chimie Industrielle, Institut de Chimie B6, University of Liège, Sart \\ Tilman, 4000 Liège, Belgium; Fax (32)4-3664435; Cior@ulg.ac.be
}

(Received: March 15, 2004; published: April 13, 2004)

\begin{abstract}
Direct methanol fuel cells (DMFCs) using a proton exchange membrane as electrolyte is an attractive option for electricity generation. The most widely used membrane in the DMFC system is based on a perfluorinated polymer bearing sulfonic acid functions like Nafion ${ }^{\circledR}$. The latter combines chemical, mechanical and thermal stability and high protonic conductivity but shows elevated methanol permeability. We propose the preparation of a novel type of hybrid membranes to tentatively solve this problem. This innovative material results from the homogeneous dispersion of a nano-scaled inorganic filler within Nafion. The filler consists of stacks of negatively charged alumino-silicate layers (Cloisite), with a positive counter-ion in the interlamellar space. The purpose of the addition of this filler is to decrease methanol diffusion through the polymer membrane without decreasing too much the ionic conductivity.
\end{abstract}

\section{Introduction}

Nowadays, fuel cells (FCs) are an environmentally friendly source of power of high energy efficiency. Direct methanol fuel cells (DMFCs) that use a proton exchange membrane (PEM) as electrolyte are an attractive option for electricity generation, because of high energy density and simplicity of operation, e.g., compared with systems that need a reformer to produce hydrogen from liquid fuel. The most widely used membrane in DMFCs is Nafion ${ }^{\circledR}$ from Dupont, a perfluorinated polymer substituted by sulfonic acid groups. This polymer combines chemical, mechanical and thermal stability, and high protonic conductivity in the hydrated state.

However, perfluorinated membranes have three major drawbacks: high production costs, elevated methanol permeability and restricted service temperature $\left(\approx 80^{\circ} \mathrm{C}\right)$. The latter limitation is related to the difficult management of water whose availability is a prerequisite for protonic conductivity.

These problems must be overcome because a high methanol crossover decreases not only the fuel efficiency, but also the cathode performance. Moreover, solid electrolyte membranes with high proton conductivity $(>0.01 \mathrm{~S} / \mathrm{cm})$ and little or no dependence on humidity above $100^{\circ} \mathrm{C}$ are very desirable, because of the beneficial 
effect of elevated temperatures on electrode kinetics, CO tolerance of the electrocatalysts and needed amount of precious Pt metals [1].

Two strategies are possible for tackling the problem. The first one consists in replacing Nafion ${ }^{\circledR}$ by alternative polymers, such as sulfonated polyetherketone [2], sulfonated polysulfone $[3,4]$, sulfonated aromatic polyimide $[5,6]$ and polybenzimidazole (PBI) doped by a strong acid, e.g., $\mathrm{H}_{3} \mathrm{PO}_{4}$ and $\mathrm{H}_{2} \mathrm{SO}_{4}[7,8]$. PBI membranes are remarkable because they do not need permanent hydratation for exhibiting high ionic conductivity, which makes their use at temperatures higher than $100^{\circ} \mathrm{C}$ feasible. The second strategy relies on the modification of ion-conducting polymers by inorganic fillers, such as silica [9], heteropolyacids [10,11], zirconium phosphate [12] and montmorillonite [13]. The addition of these fillers is supposed to improve water retention.

This study aims at dispersing a nano-scaled multi-layered alumino-silicate (montmorillonite) within Nafion ${ }^{\circledR}$. The nano-filler consists of stacks of negatively charged alumino-silicate layers, with positive counter-ions in the interlamellar space or gallery. However, it is only when this nano-filler is completely exfoliated within the polymer that its impact on polymer properties is maximum. For this purpose, the nano-filler must be made organophilic by exchanging the native inorganic counter-ions with bulky organic ones, e.g., alkyl ammonium cations. Not only the affinity of the filler to the polymer matrix is improved, but the inter-layer distance is also increased.

In addition to native montmorillonite (Cloisite $\mathrm{Na}$ ), three modified versions have been used in this study, i.e., montmorillonite with proton counter-ions (Cloisite $\mathrm{H}^{+}$) and montmorillonite with two different types of alkyl ammonium cations (Cloisite 25A and 30B) (Fig. 1). The hybrid membranes have been prepared by melt-blending the processable sulfonyl fluoride precursor of Nafion ${ }^{\circledR}$ with the nano-filler. The ionic structure of Nafion is restored by the chemical treatment of the processed nanocomposite membrane sketched in Fig. 2.<smiles>CCCCC(CC)C[N+](C)(C)C</smiles>

b)<smiles>C[N+](C)(C)CCO</smiles>

Fig. 1. Structure of the counter-ion in (a) Cloisite 25A and (b) Cloisite 30B ( $x=14$ $(5 \%), 16(30 \%)$ and $18(65 \%))$

The exfoliation of multi-layered silicates into Nafion is expected to improve the barrier properties of the polymer, particularly towards methanol, as a result of the high length-to-width ratio. In case of ideal exfoliation of the silicate sheets, the tortuosity factor $(\tau)$, defined as the ratio of the actual distance $\left(d^{\prime}\right)$ that a penetrant must travel to the shortest distance $(d)$ that it would have travelled in the absence of the layered silicate, is maximized (Fig. 3) [14]. This factor can be evaluated by Eq. (1), where $L$, $W$ and $\Phi$ are length, thickness and volume fraction of the layered silicate. $L / W$ is the anisotropy factor of the layer.

$\tau=d^{\prime} / d=1+\Phi L /(2 W)$ 

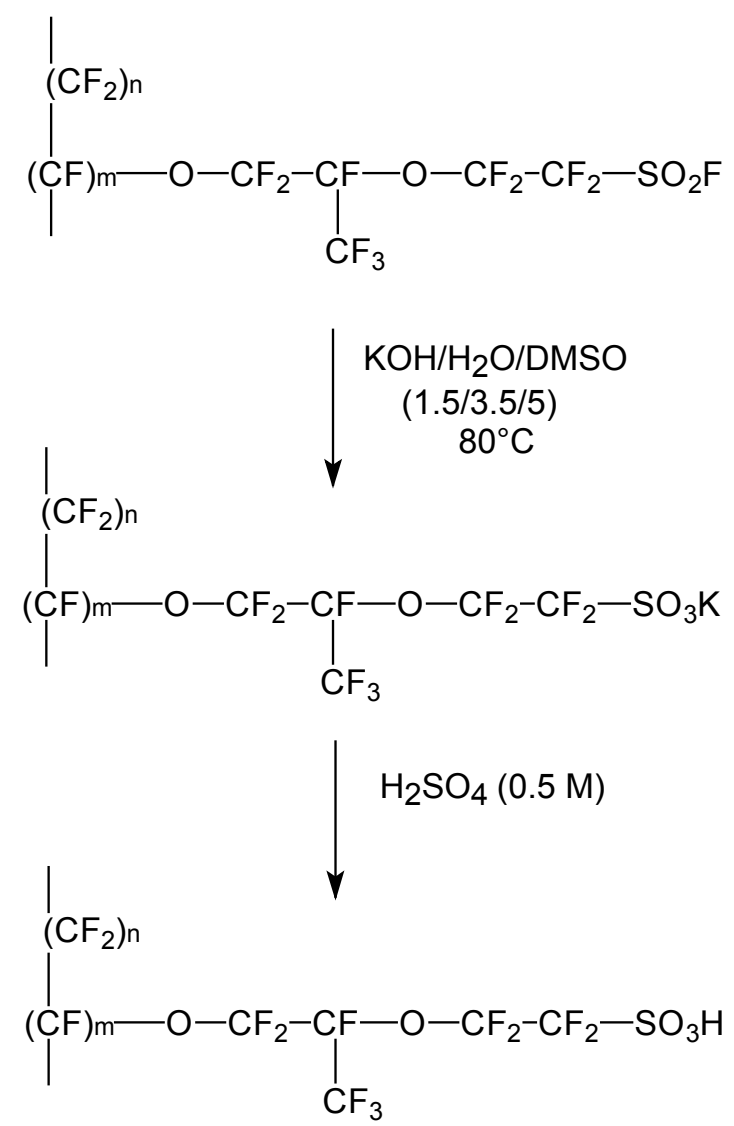

Fig. 2. Hydrolysis of the Nafion ${ }^{\circledR}$ precursor

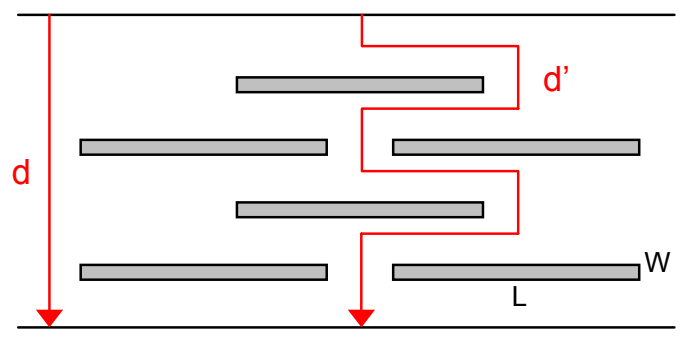

Fig. 3. Definition of the tortuosity factor

Nevertheless, the exfoliated silicate nanolayers could decrease the ionic conductivity in addition to the methanol permeability. Thus, the performance of fuel cell nanocomposite membranes should be estimated in terms of balance between protonic conductivity $(C)$ and methanol permeability $(P)$. This $C / P$ ratio $(\Delta)$, which is an efficiency indicator [15], must thus be maximized. In this work, loading and counterions of the layered nanosilicates have been modified, and the impact on the barrier properties (ionic conductivity and methanol permeability) and the performance of the membrane in a single fuel cell have been studied.

\section{Experimental part}

\section{Materials}

The Nafion ${ }^{\circledR}$ precursor, i.e., a perfluorosulfonyl fluoride copolymer resin (Nafion ${ }^{\circledR}$ R1100 resin) was supplied by lon Power Inc., Bear, DE, USA. Native sodium mont- 
morillonite (Cloisite $\mathrm{Na}$ ) with a cationic exchange capacity (CEC) in the 80 - 95 meq/100 g range and montmorillonite organomodified by non-functional alkylammonium (Cloisite 25A) and by a hydroxyl-containing alkylammonium (Cloisite 30B) (Fig. 3) were supplied by Southern Clay Products (USA). H-substituted montmorillonite (Cloisite $\mathrm{H}^{+}$) was prepared by ion exchange of $\mathrm{Na}$-montmorillonite with a hydrochloric acid solution. Typically, a 1-g sample of air-dried nano-clay was treated with $50 \mathrm{ml}$ of $0.1 \mathrm{M} \mathrm{HCl}$ solution for $3 \mathrm{~h}$ [16]. The Cloisite suspension was filtered and the final product was thoroughly washed with distilled water. The sample was then dried overnight in vacuum $\left(10^{-2} \mathrm{~mm} \mathrm{Hg}\right)$.

\section{Membrane preparation}

The nanocomposite membranes were prepared by melt-mixing the Nafion precursor with the required amount of montmorillonite at $180^{\circ} \mathrm{C}$ in a $5-\mathrm{cm}^{3} \mathrm{DSM}$ microextruder under nitrogen at $200 \mathrm{rpm}$ for $5 \mathrm{~min}$, followed by processing with a laboratory two-roll mill at $200^{\circ} \mathrm{C}$. The Nafion precursor was hydrolysed by immersion in a solution of $\mathrm{KOH} /$ water/dimethyl sulfoxide $(1.5 / 3.5 / 5)$ at $80^{\circ} \mathrm{C}$ for $2 \mathrm{~h}$, followed by the repeated immersion (three times) in a fresh solution of $\mathrm{HNO}_{3}(20$ vol.- $\%)$ for $1 \mathrm{~h}$. Before any characterization, the membranes were pre-treated in a conventional manner, i.e., $1 \mathrm{~h}$ in a boiling $5 \% \mathrm{H}_{2} \mathrm{O}_{2}$ aqueous solution, $1 \mathrm{~h}$ in boiling $1 \mathrm{M} \mathrm{H}_{2} \mathrm{SO}_{4}$ and repeated washing with Milli $\mathrm{Q}$ water $(18 \mathrm{M} \Omega)$. They were stored in deionised water.

\section{Transmission electron microscopy (TEM)}

Clay dispersions were observed with a transmission electron microscope Philips M100 at an accelerating voltage of $100 \mathrm{kV}$. Thin sections $(90 \mathrm{~nm})$ were prepared by ultramicrotomy (Ultracut $\mathrm{E}$ from Reichert-Jung) at $-130^{\circ} \mathrm{C}$. Micrographs were analyzed by using the KS 100 (Kontron Imaging System) software.

\section{Methanol permeability [17]}

Methanol permeability was measured with a two-compartment cell. One compartment $\left(V_{\mathrm{A}}=100 \mathrm{ml}\right)$ was filled with a mixture of methanol (8 vol.- $\left.\%\right)$ and 1-butanol $(0.2$ vol.- $\%)$ in deizoned water. The other compartment $\left(V_{B}=100 \mathrm{ml}\right)$ was filled with a 1-butanol (0.2 vol.-\%) solution in deizoned water. The membrane (surface area $=28$ $\mathrm{cm}^{2}$ ) was clamped between the two compartments and the methanol concentration in the receiving compartment was measured as a function of time by gas chromatography using 1-butanol as an internal reference. It may be shown that the evolution of this concentration with time is given by

$c_{\mathrm{B}}(t)=\frac{A D K}{V_{\mathrm{B}} L} c_{\mathrm{A}}\left(t-t_{0}\right)$

where $c$ is the methanol concentration, $A$ and $L$ are the membrane area and thickness, respectively, $D$ and $K$ stand for methanol diffusivity and partition coefficient between the membrane and the adjacent solution, respectively. It is assumed that $D$ is constant throughout the membrane and $K$ is independent of concentration. The product $D K$ is the membrane permeability, which is calculated from the slope of the straight line of $C_{B} \cdot L$ as a function of time. 


\section{Ionic conductivity}

The cell is schematized in Fig. 4. Current was fed to the membrane $\left(4 \times 1 \mathrm{~cm}^{2}\right)$ by two platinum (wire) electrodes $4 \mathrm{~cm}$ apart. Two platinum wires $2 \mathrm{~cm}$ apart allowed the potential drop along the membrane to be measured. These electrodes were screwed in a polycarbonate support riddled with holes that allow the membrane to be equilibrated with the atmosphere.

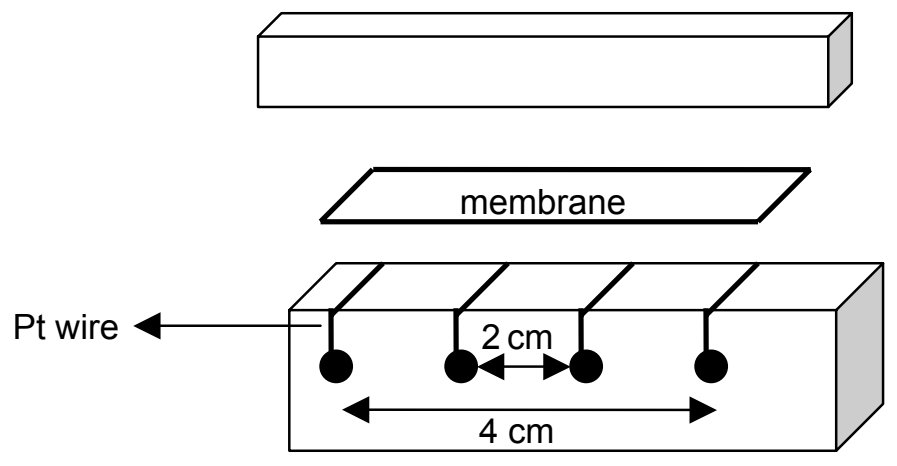

Fig. 4. Schematic view of the cell used for the measurement of ionic conductivity

Measurements are reported for $100 \%$ humidity, at room temperature. Membrane conductivity was thus measured in the longitudinal direction and calculated by

$\sigma=\frac{1}{R S}$

where $\sigma$ is the ionic conductivity, I the distance between the reference electrodes, $R$ is the resistance of the membrane, and $S$ is the cross-sectional area.

Impedance was measured in the frequency region from $1 \mathrm{~Hz}$ to $500 \mathrm{kHz}$, with a potentiostat and a frequency-response analyser (Autolab model PGSTAT 30).

\section{Small size fuel cell}

The gas diffusion layer was a $20 \%$ polytetrafluoroethylene-treated carbon cloth (Quintech). A weighed amount of $30 \mathrm{wt} . \% \mathrm{Pt} / \mathrm{Ru}$ on carbon black (anode, Johnson Matthey) or $20 \% \mathrm{Pt} / \mathrm{C}$ (cathode, E-TEK) was suspended in a 2:1 mixture of Millipore conductivity water and isopropanol. Appropriate amounts of $5 \%$ Nafion solution in water/alcohol mixture were added to the suspension that was carefully stirred in an ultrasonic bath.

These catalysed inks were brushed onto the carbon cloth (geometric area of $16 \mathrm{~cm}^{2}$ ) and dried at $80^{\circ} \mathrm{C}$. Two or three layers of ink were spread until catalyst loading was $0.6-7 \mathrm{mg} / \mathrm{cm}^{2}$. Before cell assembly, a $5 \%$ Nafion solution in a water/alcohol mixture was deposited $\left(0.6 \mathrm{mg} / \mathrm{cm}^{2}\right)$ on the catalysed carbon electrodes. The membrane $(7 \mathrm{x}$ $7 \mathrm{~cm}$ ) was placed between the two electrodes and this assembly was pressed between aluminium plates at $120 \mathrm{kgf} / \mathrm{cm}^{2}$ and $130^{\circ} \mathrm{C}$ for $4 \mathrm{~min}$.

The membrane/electrode assembly (MEA) was clamped between two stainless steel plates with two flow channels (area $16 \mathrm{~cm}^{2}$ ). Each side of the electrode was sealed with a silicon gasket. The fuel cell was placed in an oven in order to regulate the temperature. 
A $1 \mathrm{M}$ methanol solution was circulated with a chromatic pump LKB. The flow rate was $0.5 \mathrm{ml} / \mathrm{min}$.

Oxygen was stored in pressurised cylinders, supplied $(30 \mathrm{ml} / \mathrm{min})$ through a mass flow controller (BROOKS BS5058) and humidified at room temperature.

The MEA's were tested at three temperatures, i.e., room temperature, 60 and $80^{\circ} \mathrm{C}$. They were previously maintained under atmospheric pressure overnight, with a continuous supply of the anode by $1 \mathrm{M}$ methanol solution in water (Millipore 18MO, $0.5 \mathrm{ml} / \mathrm{min}$ ) and the cathode by argon $(45 \mathrm{ml} / \mathrm{min})$. Before measurement, argon was replaced by oxygen. Each polarisation curve was stabilised by potentiometry (zero current at the open circuit potential (OCP)) for at least one hour, followed by the record of the current-voltage curve.

All the measurements were carried out with the potentiostat/galvanostat Autolab (PGSTAT 30).

\section{Results and discussion}

\section{Membrane preparation}

Nafion ${ }^{\circledR}$ is a perfluorinated polymer substituted by sulfonic acid groups. In the dry state, these ionic groups associate into clusters, which results in polymer crosslinking and prevents it from being melt-processed below the degradation temperature. Two main strategies can however make Nafion ${ }^{\circledR}$ melt-processable. The first method consists in converting the acid groups into salts with a large cation. These voluminous counter-ions restrict the ionic clustering to the point where the polymer can be molten at a reasonable temperature $\left(200^{\circ} \mathrm{C}\right)$ [18]. The second strategy is based on the use of a Nafion ${ }^{\circledR}$ precursor, i.e., the sulfonyl fluoride derivative, which does not form clusters and is easily molten $\left(180^{\circ} \mathrm{C}\right)$. Sulfonyl fluoride is easily converted into acid by immersion in an appropriate solution (Fig. 2). This method has been used in this work.

\section{Morphological studies}

Dispersion of 2 wt.-\% of native and modified montmorillonite (MMT) in Nafion ${ }^{\circledR}$ is compared at Fig. 5. TEM observations show that the nano-filler is dispersed to an extent that strongly depends on the counter-ion of the silicate layers. In case of $\mathrm{Na}^{+}$ and $\mathrm{H}^{+}$counter-ions, no exfoliation of the filler is observed, but rather microscopic stacks are dispersed within the polymer matrix. Lack of affinity between the partly sulfonated perfluorinated chains and the internal surface of the nano-clay can account for this crude dispersion.

Substitution of bulky organic counter-ions (Cloisite 25A) for $\mathrm{Na}^{+}$does not improve this situation. The alkyl substituents of the ammonium are thus unable to promote favourable interactions with the perfluorinated polymer. In contrast, when MMT is modified by ammonium cations that bear $\mathrm{OH}$ groups (Cloisite $30 \mathrm{~B}$ ), clay dispersion is remarkably improved. Now, highly anisotropic nano-objects are observed, which are however assemblies of few alumino-silicate layers. Even though exfoliation is not complete, this dispersion morphology imparts anisotropic properties to the matrix, which should improve the barrier properties. Clearly, the hydroxyl groups available in the interlamellar space of Cloisite $30 \mathrm{~B}$ interact favourably with Nafion ${ }^{\circledR}$, to the point where polymer chains can penetrate the clay galleries, which contributes to the 
delamination of the alumino-silicate stacks by the shearing forces during melt blending.

a)

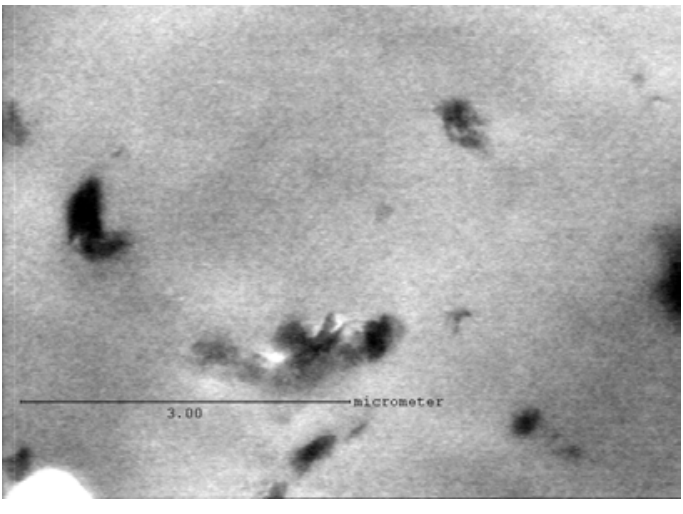

$1 \mu \mathrm{m}$

c)

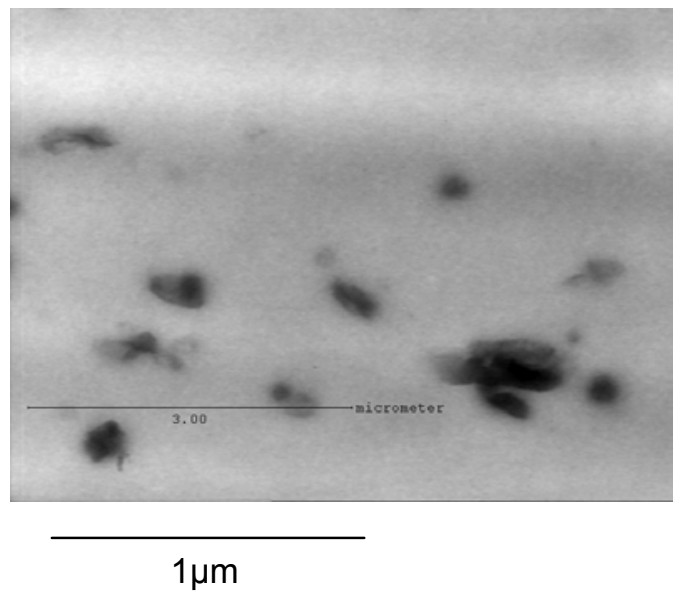

b)

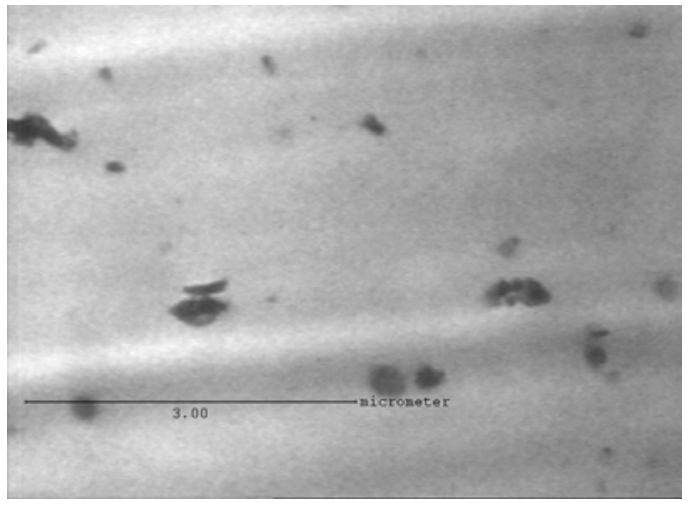

$1 \mu \mathrm{m}$ d)

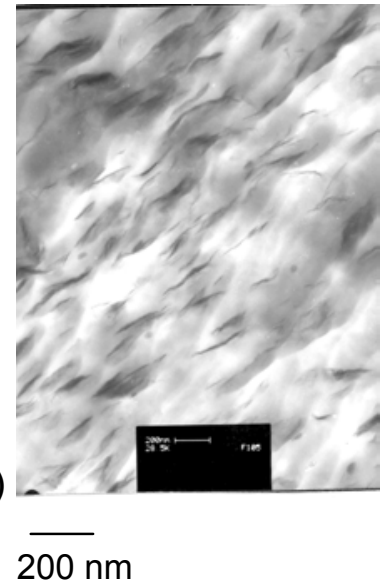

Fig. 5. TEM micrographs for Nafion ${ }^{\circledR}$ membranes filled with 2 wt.- $\%$ of (a) Cloisite $\mathrm{Na}^{+}$, (b) Cloisite $\mathrm{H}^{+}$, (c) Cloisite 25A and (d) Cloisite 30B

\section{Methanol permeability}

Methanol permeability, i.e., the $D K$ factor, of the Nafion/Cloisite hybrid membranes has been determined from the slope of the time dependence of the $c_{\mathrm{B}} L$ product, as shown in Fig. 6 . The influence of both the counter-ion and the amount of nano-clay within the polymer matrix has been studied. The accordingly calculated $D K$ values are reported in Fig. 7. They depend on the filler content in close relation to the counter-ion within the clay gallery. MMT containing $\mathrm{Na}$ and alkylammonium cations, respectively, is responsible for a methanol permeability that increases continuously with filler loading. Thus the barrier properties of Nafion ${ }^{\circledR}$ are degraded by the nanoclay, more likely because of a very crude dispersion. A lack of interaction between the filler and the polymer has the additional disadvantage of favouring voids at the polymer/filler interface, thus preferential paths for the methanol diffusion. In contrast, dispersion of Cloisite $30 \mathrm{~B}$ within Nafion ${ }^{\circledR}$ improves remarkably the barrier properties against methanol diffusion, even at a very low filler content. The $D K$ factor decreases by c. $60 \%$ for 0.5 wt.- $\%$ of Cloisite $30 \mathrm{~B}$ with respect to the neat polymer. This observation is a direct consequence of the much higher degree of delamination of this modified montmorillonite, which increases the number of smaller and more anisotropic particles and accordingly the diffusion distance that methanol must travel 
to cross the membrane. However, beyond $0.5 \mathrm{wt} .-\%$ filler, the $D K$ factor does not decrease further, but rather increases slightly with the clay content. This behaviour is consistent with the thickness of the dispersed domains $(W)$ that increases with the volume fraction of the filler $(\Phi)$.

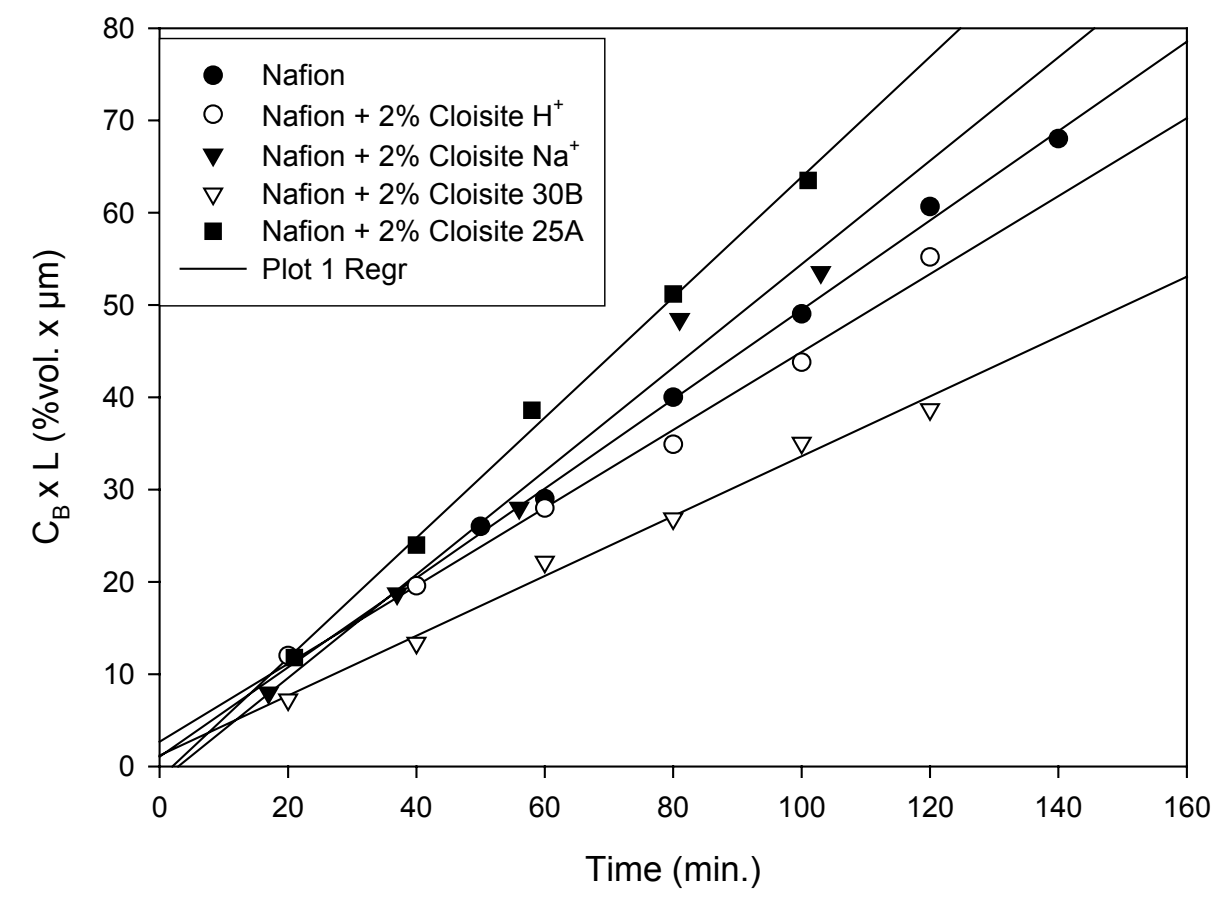

Fig. 6. Methanol permeability for Nafion ${ }^{\circledR}$ membranes modified by 2 wt.- $\%$ of (a) Cloisite $\mathrm{Na}^{+}$, (b) Cloisite $\mathrm{H}^{+}$, (c) Cloisite 25A and (d) Cloisite 30B. (Lines are guides for the eyes)

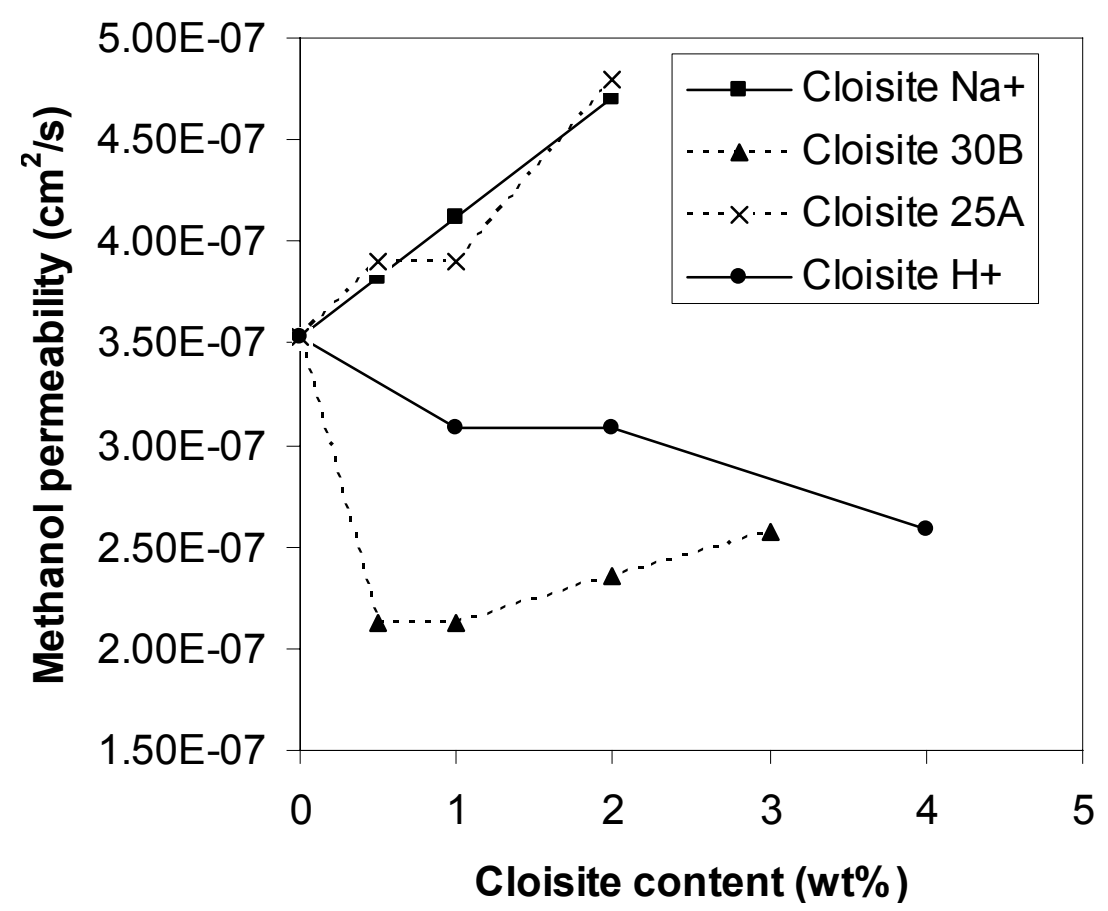

Fig. 7. Methanol permeability of Nafion ${ }^{\circledR}$ membranes filled with Cloisite $\mathrm{H}^{+}$, Cloisite $\mathrm{Na}^{+}$, Cloisite 25A and Cloisite 30B as a function of the filler content. (Lines are guides for the eyes) 
It is a general observation that the exfoliation degree of the nano-clays decreases when the filler content is increased [19]. This observation thus accounts for a tortuosity factor largely independent of the Cloisite 30B content beyond $0.5 \%$. For membranes filled with Cloisite $\mathrm{H}^{+}$, an intermediate behaviour was found. The decrease in $D K$ is less pronounced compared to Cloisite 30B, which is the consequence of a comparatively lower degree of exfoliation and anisotropy of Cloisite $\mathrm{H}+$, as confirmed by TEM. However, in contrast to Cloisite 25A and native MMT, both the dispersion of the nano-filler within the polymer matrix and its adhesion to it are sufficiently high for a barrier effect to be effective. All in all these results confirm that the exfoliation of layered nano-clays is the key parameter for a successful control of the methanol permeability through Nafion ${ }^{\circledR}$. Further effort is necessary for disassembling the nano-filler into hopefully individual highly anisotropic inorganic sheets with a preferential orientation perpendicular to the diffusion direction.

\section{lonic conductivity}

Fig. 8 shows how the ionic conductivity of Nafion ${ }^{\circledR}$ depends on the content of MMT containing different counter-ions. The ionic conductivity measured for a commercial Nafion 117 membrane $(0.11 \mathrm{~S} / \mathrm{cm})$ is also plotted in this figure. It appears that the ionic conductivity of the Nafion ${ }^{\circledR}$ membrane prepared by our method is essentially the same (within the limits of experimental error) as the commercial one $(0.1 \mathrm{~S} / \mathrm{cm})$. The size of the counter-ion of MMT has an important impact on the ionic conductivity of Nafion ${ }^{\circledR}$. At constant Cloisite content, the ionic conductivity decreases as much the counter-ion is bulky, thus from proton to alkylammonium. A possible explanation might be found in an exchange of the protons of sulfonic acid groups of Nafion ${ }^{\circledR}$ by counter-ions of the nano-clay. In this respect, it is worth noting that the ionic conductivity is basically the same for the two ammonium-containing MMT, i.e., Cloisite 25A and Cloisite 30B, although Cloisite 30B is much better dispersed in the membrane than Cloisite 25A. Moreover, Cloisite $\mathrm{H}^{+}$has no deleterious effect on the ionic conductivity at least until a content of 2 wt.-\%. The curve for Cloisite $\mathrm{Na}^{+}$falls in between Cloisite $\mathrm{H}^{+}$and the ammonium-containing MMT, in direct relation to the size, and thus the mobility, of the counter-ions.

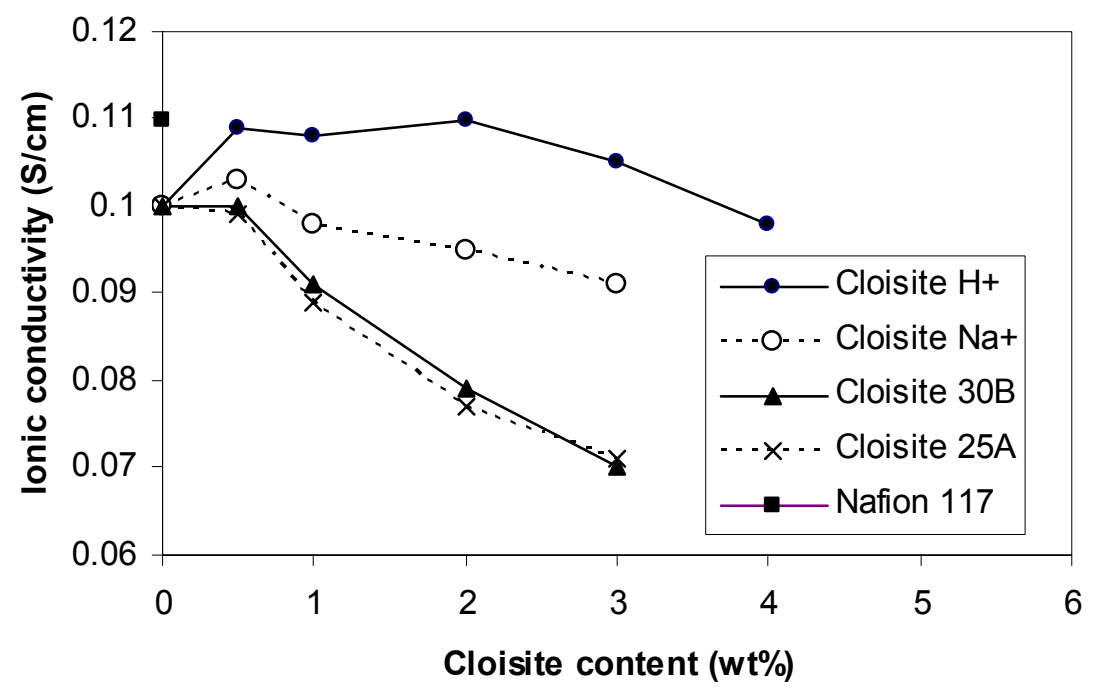

Fig. 8. Ionic conductivity of Nafion ${ }^{\circledR}$ membranes filled with Cloisite $\mathrm{H}^{+}$, Cloisite $\mathrm{Na}^{+}$, Cloisite 25A and Cloisite 30B as a function of the filler content. (Lines are guides for the eyes) 
Because addition of nano-clays within Nafion ${ }^{\circledR}$ has an effect on two key properties of the membrane, viz., ionic conductivity $(C)$ and methanol permeability $(P)$, it is essential to identify the nano-filler for which the $C / P$ ratio is the highest. Fig. 9 illustrates the dependence of the $C / P$ ratio on the nano-filler content. In contrast to Cloisite $\mathrm{Na}^{+}$and Cloisite 25A that have to be disregarded, Cloisite $\mathrm{H}^{+}$improves the performance of the membranes. In case of Cloisite $30 \mathrm{~B}$, the $C / P$ ratio passes through a maximum at low nano-filler content and then it decreases as a result of the marked decrease in ionic conductivity. Cloisite $30 \mathrm{~B}$ and Cloisite $\mathrm{H}^{+}$are thus the more promising candidates for improving the properties of Nafion ${ }^{\circledR}$ fuel cell membranes. These nano-fillers have however a diametrically opposed effect on these properties. Indeed, Cloisite $\mathrm{H}^{+}$has a detrimental effect on the methanol permeability whereas the ionic conductivity is depressed in the presence of Cloisite 30B. The questions addressed now are how to improve dispersion and exfoliation of Cloisite $\mathrm{H}^{+}$in Nafion ${ }^{\circledR}$ and how to compensate the loss in ionic conductivity when Cloisite 30B is the nano-filler. Effort will be made in this direction in the future.

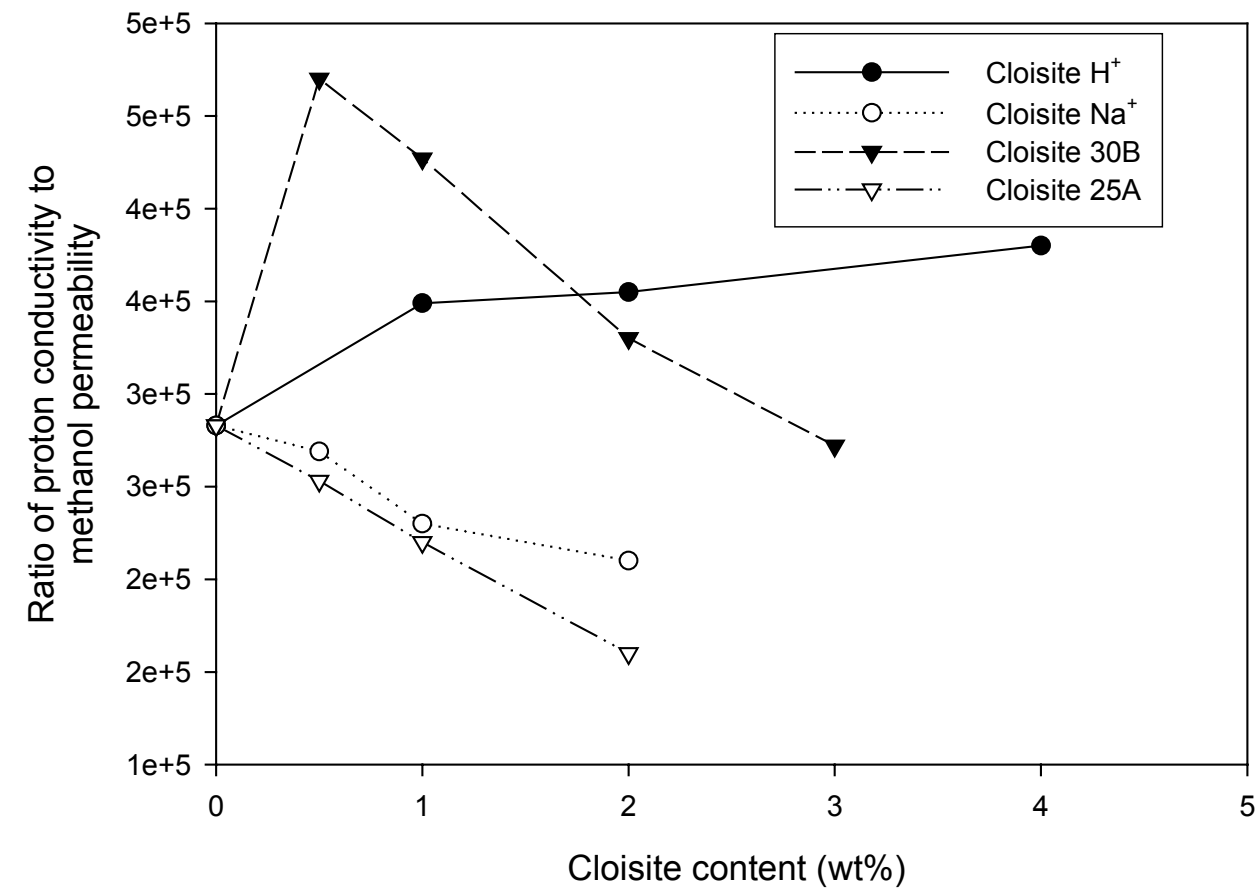

Fig. 9. $\mathrm{ClP}$ ratio of Nafion ${ }^{\circledR}$ membranes filled with Cloisite $\mathrm{H}^{+}$, Cloisite $\mathrm{Na}^{+}$, Cloisite $25 \mathrm{~A}$ and Cloisite $30 \mathrm{~B}$ as a function of the filler content. (Lines are guides for the eyes)

\section{Fuel cell experiment}

Nafion ${ }^{\circledR}$ membranes filled with 2 wt.- $\%$ of Cloisite have been tested in a model fuel cell at three different temperatures (room temperature, 60 and $80^{\circ} \mathrm{C}$ ). All the measurements were IR corrected and Nafion 117 was used as a reference. Once again, the polarization curves depend on the counter-ion of the nano-clay, as shown in Fig. 10. Cloisite 30B is by far the worse nano-filler. However, a comparison of the curves at different contents of Cloisite $30 \mathrm{~B}$ confirms that $0.5 \%$ is the best content, as previously concluded from the C/P ratio (Fig. 9). Any increase beyond that content has a deleterious effect on the membrane performance. At constant nano-clay content of 2 wt.-\%, addition of Cloisite $\mathrm{Na}^{+}$has no beneficial effect (Fig. 10). Only Cloisite $\mathrm{H}^{+}$can impart better properties at the three temperatures under consider- 
ation. For instance, at $80^{\circ} \mathrm{C}$ and a potential of $0.3 \mathrm{~V}$, the current density is $0.1 \mathrm{~A} / \mathrm{cm}^{2}$ for the membrane filled with Cloisite $\mathrm{H}^{+}$compared to $0.06 \mathrm{~A} / \mathrm{cm}^{2}$ for Nafion 117 . This benefit basically results from (although slightly) decreased methanol permeability at quasi-constant ionic conductivity. So, the priority should be given to strategies able to exfoliate Cloisite $\mathrm{H}^{+}$as much as possible in Nafion ${ }^{\circledR}$.

At the time being, the polarization curves cannot be measured at temperatures higher than $80^{\circ} \mathrm{C}$ for technical reasons, thus we cannot assess whether the addition of nano-clays may be beneficial or not to water retention and performances at temperatures higher than $100^{\circ} \mathrm{C}$.

(a) room temperature:

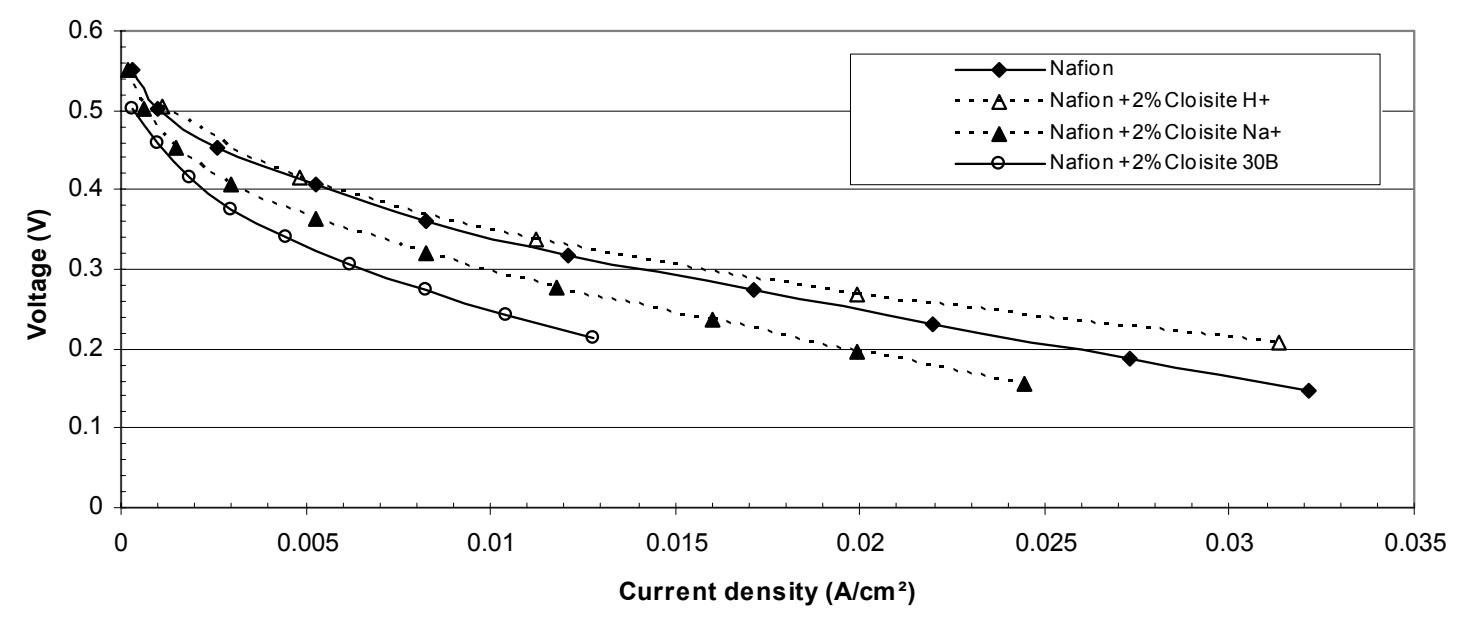

(b) $60^{\circ} \mathrm{C}$ :

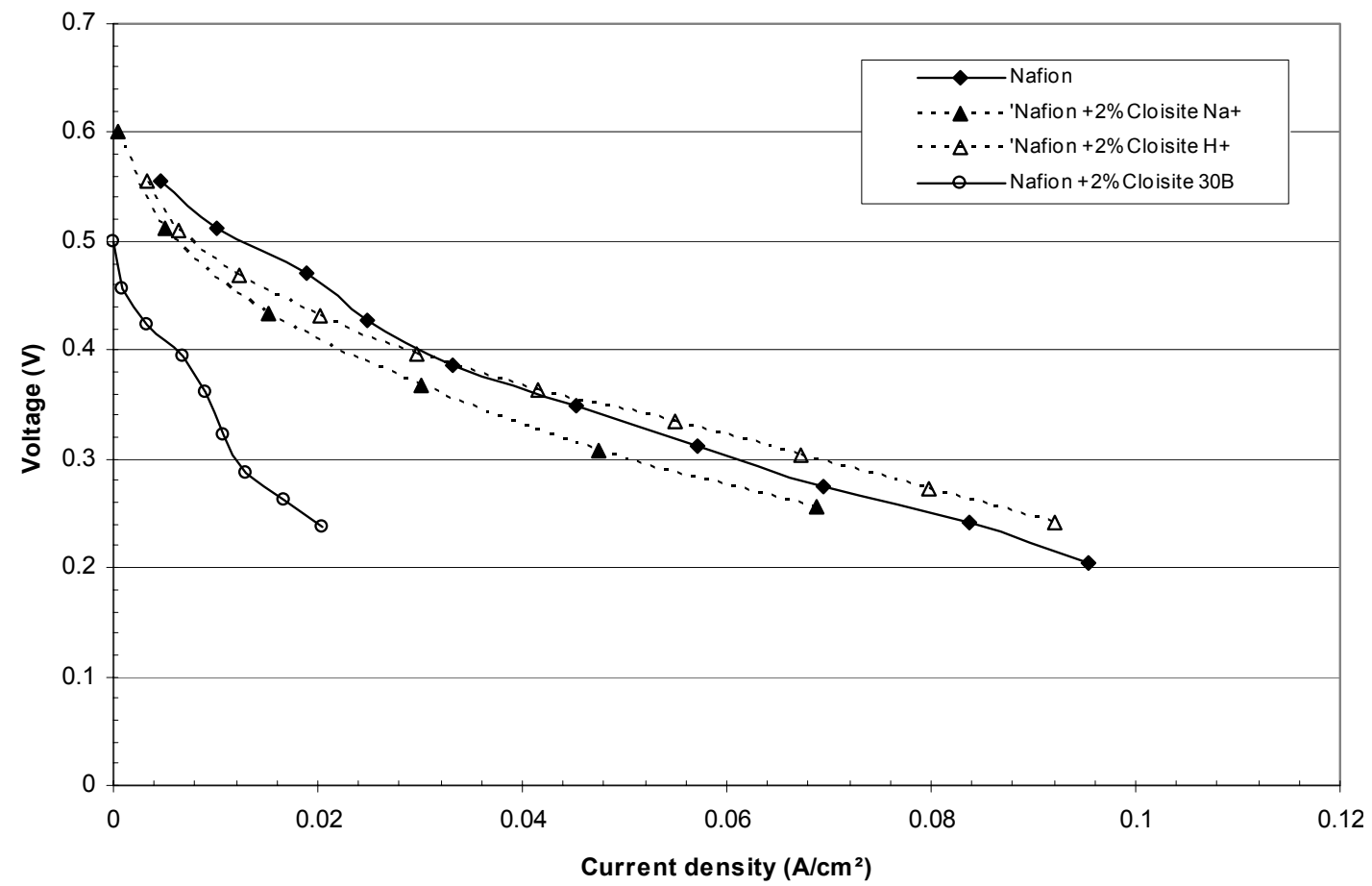

Fig. 10. Polarization curves for modified Nafion ${ }^{\circledR}$ membranes at (a) room temperature, (b) $60^{\circ} \mathrm{C}$ and (c) $80^{\circ} \mathrm{C}$. (Lines are guides for the eyes) 
(c) $80^{\circ} \mathrm{C}$ :

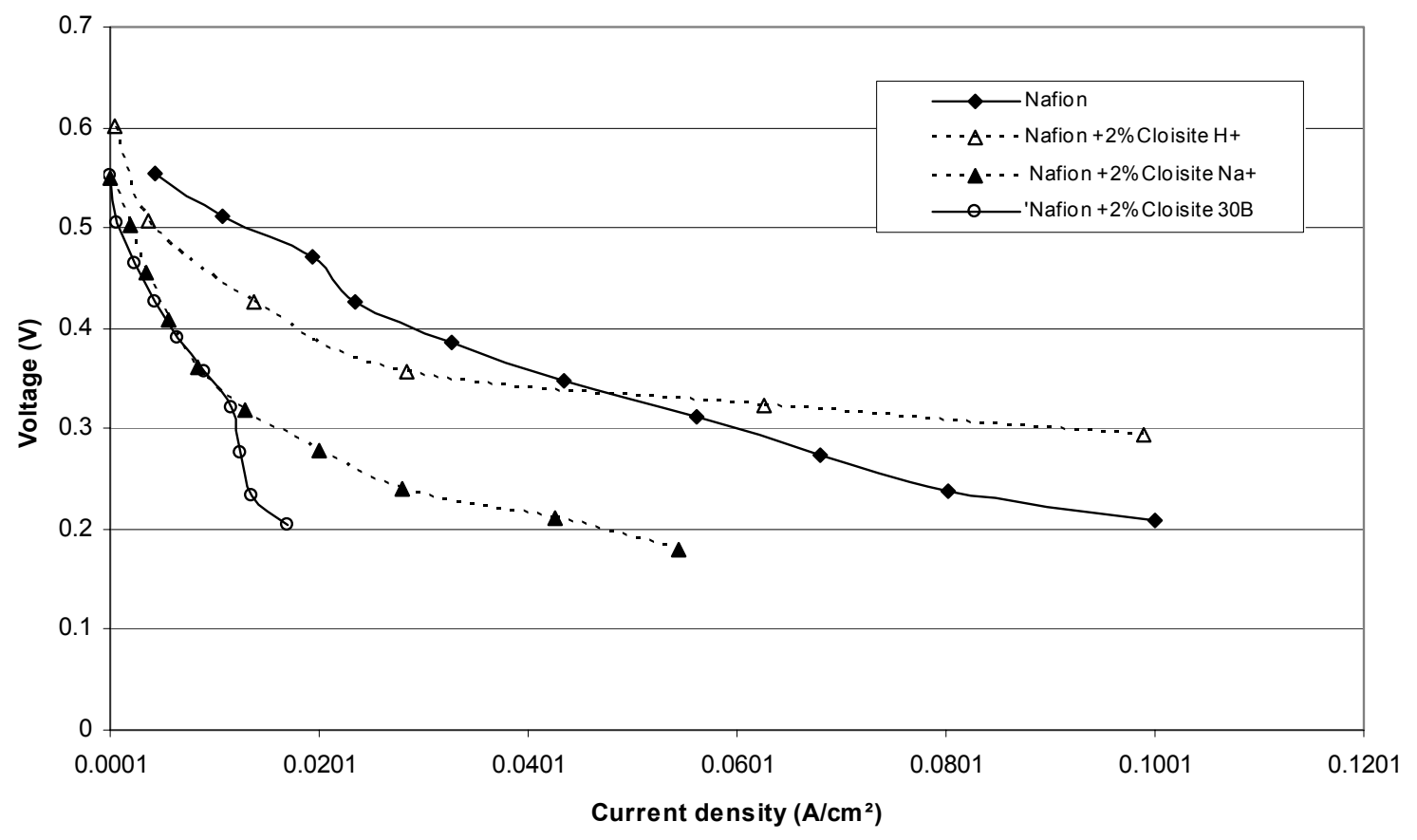

Fig. 10c.

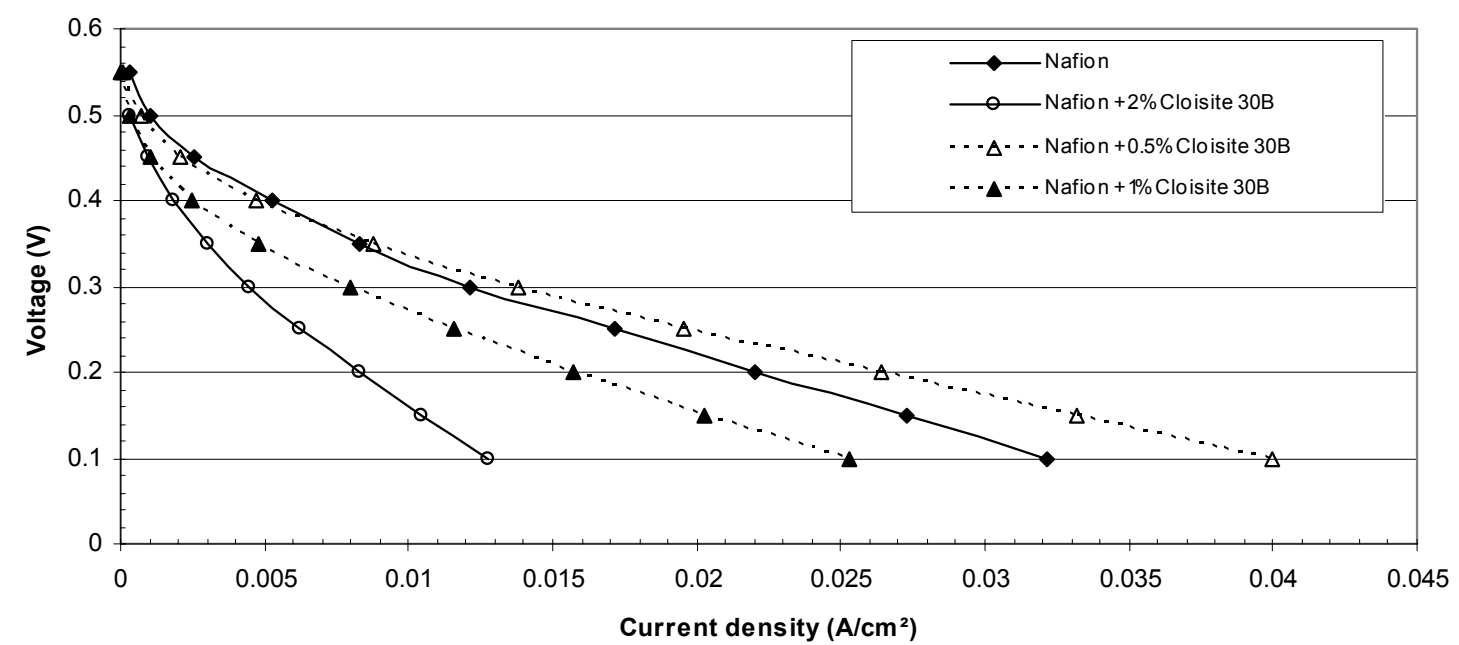

Fig. 11. Polarization curves for Nafion ${ }^{\circledR}$ membranes filled with Cloisite $30 \mathrm{~B}$ at room temperature

\section{Conclusion}

For MMT to be dispersible within Nafion ${ }^{\circledR}$, the $\mathrm{Na}^{+}$counter-ions of the native nanoclay have to be exchanged by alkylammonium for making it organophilic. This modification is however not sufficient for promoting specific interactions between the layered silicate and the polymer. A way to tackle this problem is to attach a hydroxyl group at the end of at least part of the alkyl chains, as is the case for Cloisite 30B. When MMT is finely dispersed within the membrane, the barrier properties are improved as assessed by lower methanol permeability. This improvement is however observed at the expense of the ionic conductivity, more likely as a result of the exchange of protons of Nafion ${ }^{\circledR}$ with much less mobile ammonium cations of the nano-clay. This hypothesis might explain that the best performances are observed 
with a Cloisite $30 \mathrm{~B}$ content as low as $0.5 \%$. Any further increase of this loading has a detrimental effect on the ionic conductivity/methanol permeability balance and on the polarization curves measured with a small-size fuel cell. Cloisite $\mathrm{H}^{+}$is another interesting layered nano-filler, which has no deleterious impact on the ionic conductivity and decreases slightly the methanol permeability. Any progress in the delamination of this nano-clay within Nafion ${ }^{\circledR}$ should improve considerably the performances of the membranes, which justifies that a special effort is devoted now to this direction.

Acknowledgement: CERM is grateful to the Région Wallonne for support in the frame of the NANOCELL program. CERM is also indebted to the 'Belgian Science Policy' for financial support in the frame of the 'Interuniversity Attraction Poles Programme (PAI V/03)'.

[1] Jannasch, P.; Current Opinion in Colloid Interface Science 2003, 8, 96.

[2] Kreuer, K. D.; J. Membr. Sci. 2001, 185, 29.

[3] Wang, F.; Hickner, M.; Kim, Y. S.; Zawodzinski, T. A.; McGrath, J. E.; J. Membr. Sci. 2002, 197, 231.

[4] Poppe, D.; Frey, H.; Kreuer, K. D.; Heinzel, A.; Mülhaupt, R.; Macromolecules 2002, 35, 7936.

[5] Guo, X.; Fang, J.; Watari, T.; Tanaka, K.; Kita, H.; Okamoto, K.; Macromolecules 2002, 35, 6707.

[6] Besse, S.; Capron, P.; Diat, O.; Gebel, G.; Jousse, F.; Marsacq, D.; Pineri, M.; Marestin, C.; Mercier, R.; J. New Mater. Electrochem. Syst. 2002, 5, 109.

[7] Pu, H.; Meyer, W. H.; Wegner, G.; J. Polym. Sci., Polym. Phys. 2002, 40, 663.

[8] Qingfeng, L.; Hjuler, H. A.; Bjerrum, N. J.; J. Appl. Electrochem. 2001, 31, 773.

[9] Miyake, N.; Wainright, J. S.; Savinell, R. F.; J. Electrochem. Soc. 2001, 148, A898.

[10] Staiti, P.; Aricò, A. S.; Baglio, V.; Lufrano, F.; Passalacqua, E.; Antonucci, V.; Solid State lonics 2001, 145, 101.

[11] Tazi, B.; Savadogo, O.; Electrochim. Acta 2000, 45, 4329.

[12] Bonnet, B.; Jones, D. J.; Roziere, J.; Tchicaya, L.; Alberti, G.; Casciolo, M.; Massinelli, L.; Bauer, B.; Peraio, A.; Ramunni, E.; J. New Mater. Electrochem. Syst. 2000, 3, 87.

[13] Jung, D. H.; Cho, S. Y.; Peck, D. H.; Shin, D. R.; Kim, J. S.; J. Power Sources 2003, 118, 205.

[14] Bharadwaj, R. K.; Macromolecules 2001, 34, 9189.

[15] Kim, J.; Kim, B.; Jung, B.; J. Membr. Sci. 2002, 207, 129.

[16] Aliouane, N.; Hammouch, A.; De Doncker, R. W.; Telli, L.; Boutahala, M.; Brahimi, B.; Solid State Ionic 2002, 148, 103.

[17] Tricoli, V.; Carretta, N.; Bartolozzi, M.; J. Electrochem. Soc. 2000, 147, 1286.

[18] Cable, K. M.; Croley, T. L.; Moore, R. B.; Polym. Prepr. 1993, 34, 881.

[19] Alexandre, M.; Dubois, P.; Mater. Sci. Eng. 2001, 28, 1. 